\title{
Pułapka umasowienia - o sprawczości jednostek w umasowionym systemie szkolnictwa wyższego
}

\begin{abstract}
STRESZCZENIE. Powszechna potrzeba studiowania i zdobywania wykształcenia wyższego jest w ostatnich latach zarówno w dyskursie akademickim, jak i publicznym uznawana za wynik studenckiej irracjonalności. Studenci mają poddawać się kulturowemu „mitowi wykształcenia wyższego" czy marketingowym zabiegom uczelni, podejmując decyzję, która z ekonomicznego punktu widzenia jest - według krytyków umasowienia - nie do obrony. Celem tego artykułu jest przedstawienie alternatywy wobec opisanego powyżej sposobu myślenia o jednostkowej sprawczości, racjonalności i edukacyjnym przymusie. Staram się pokazać, że negatywne konsekwencje umasowionego wykształcenia są wynikiem ekonomicznie racjonalnych decyzji zdobywających je jednostek. Umasowienie ma bowiem wiele cech społecznej pułapki, tzn. procesu społecznego, w którym indywidualna racjonalność generuje stany suboptymalne z perspektywy wspólnoty. Teoria społecznych pułapek pozwala mi również wyjaśnić, w jaki sposób rozproszone decyzje jednostek generują nieformalny „przymus szkolny” dotyczący szkolnictwa wyższego i w jaki sposób przymus ten negatywnie wpływa na perspektywy reformy systemu.
\end{abstract}

SŁOWA KLUCZOWE: wykształcenie wyższe, umasowienie, wykształcenie elitarne, pułapki społeczne, dobra pozycjonalne

\section{Wprowadzenie}

Studia wyższe są ostatnim szczeblem wykształcenia, nieobjętym w krajach rozwiniętych obowiązkiem szkolnym. Pomimo tego od początku XX wieku liczba studentów wzrosła ponad trzystukrotnie (Schofer i Meyer 2005; Foskett i Maringe 2010). Gwałtowność tego procesu sprawiła, że demokratyzacja dostępu do wykształcenia wyższego pozostaje kwestią politycznie kontrowersyjną, budząc szczególnie w okresach gospodarczych i społecznych kryzysów wiele negatywnych emo- 
cji pośród akademików i studentów, klasy politycznej oraz publicystów. Ta krytyka umasowienia (czy - gdy wypowiadają się akademicy - sposobu, w jaki wpłynęło ono na uniwersytet) natrafia w krajach demokratycznych na istotne bariery. Ponieważ edukacja wyższa nie jest obowiązkowa, więc za rozwój oferujących ją instytucji, i wynikające z tego negatywne konsekwencje takie jak inflacja dyplomów czy spadek jakości nauczania, odpowiedzialni są sami studenci. Poza rzadkimi okresami wyhamowania wzrostu to ich pragnienie zdobycia edukacji i skłonność do ponoszenia w tym celu znacznego wysiłku i kosztów napędza niekontrolowany rozwój szkolnictwa wyższego. Systemy, w których istnieją ku temu warunki instytucjonalne (możliwość tworzenia szkół prywatnych czy odpowiednie regulacje działania szkół publicznych) - nawet przy braku rzeczywistego przymusu szkolnego - zmierzają, w oparciu o indywidualny popyt, najpierw ku umasowieniu, a później - upowszechnieniu edukacji wyższej (Trow 2007).

Wpływ sprawstwa (agency) kupujących usługi edukacyjne jednostek na rozwój szkolnictwa wyższego bywa rozmaicie interpretowany. W publicznym i akademickim dyskursie ostatnich lat edukacyjne ambicje mas są często uznawane za efekt oddziaływania, irracjonalnych w swej istocie, czynników kulturowych:

Rynek usług edukacyjnych w wypadku szkół wyższych był stymulowany nie przez normalne mechanizmy rynkowe sterowane potrzebami rynku pracy, lecz symulakrami w postaci projekcji i wyobrażeń samych kandydatów. Nic więc dziwnego, że uzyskane wykształcenie w efekcie okazało się swego rodzaju symulakrum (Kobylarek 2013: 121).

Równie często jak stwierdzenia odnoszące się do „mitu wykształcenia wyższego" napotykamy mniej lub bardziej bezpośrednio formułowaną tezę o „oszustwie” dokonywanym przez szkoły wyższe czy państwo promujące masowe wykształcenie (Stankiewicz 2014a). Obie te strategie, a także inne formy publicznej analizy studenckiego wpływu na kształt systemów szkolnictwa wyższego opierają się na założeniu o fundamentalnej irracjonalności mas decydujących się na studiowanie. Zadaniem akademika, polityka czy publicysty stojącego naprzeciw ludowej ambicji jest w takiej sytuacji odnalezienie źródła popełnianego przez jednostki „błędu" i jego korekta za pomocą środków instytucjonalnych czy perswazyjnego dyskursu.

Uznając umasowienie za wynik pomyłki albo braku rozsądku studiujących (czy ich niewykształconych rodzin), aktorzy społeczni zdają się zakładać, że masowe wybory są dokonywane w warunkach ekonomicznej wolności (ci, którzy studiują, nie robią tego ze względów finansowych, studiowanie jest wbrew ich najlepszym interesom w tej kwestii) i mentalnej niewoli (pęd do wykształcenia jest wynikiem iluzji, mitu czy oszustwa). Rosnący współczynnik skolaryzacji należałoby w takich warunkach uznać za wynik zbiorowej psychozy, a rozwiązanie trudnej sytuacji szkolnictwa wyższego polegałoby na odebraniu sterów kształtującym system swoim popytem na wykształcenie studentom i przekazanie ich w ręce aktorów bardziej 
odpowiedzialnych - ekspertów, pracodawców czy władz uniwersyteckich (Stankiewicz 2012; 2014a).

Celem tego artykułu jest przedstawienie alternatywy wobec opisanego powyżej sposobu myślenia o jednostkowym sprawstwie, racjonalności i edukacyjnym przymusie oraz próba skonstruowania teoretycznej ramy, pozwalającej na zrozumienie, w jaki sposób umasowienie wynika z wyborów jednostek, ale też jak system wolnych wyborów może stworzyć przymus nie tyle mentalnej, ile ekonomicznej natury. Zrozumienie natury tego „nieformalnego przymusu szkolnego” może pozwolić na wyjaśnienie jednokierunkowości i dynamizmu umasowienia, bez odnoszenia się do wyjaśnień kulturowych, a także, mam nadzieję, na zakwestionowanie powszechnych, lecz niezgodnych z dostępnymi danymi empirycznymi przekonań dotyczących pożądanego kierunku reform systemu szkolnictwa wyższego.

\section{Funkcja dyplomów}

Umasowienie wydaje się poruszać tylko w jednym kierunku. Odstępstwa od tej reguły wystąpiły w USA w latach 70., w Polsce w 80. i podczas najostrzejszej fazy kryzysu Unii Europejskiej, gdzie między 2010 a 2012 r. stopień skolaryzacji na poziomie wyższym spadł o 5\% (OECD 2014a). Poza tymi, bez wyjątku przypadającymi na okresy długotrwałego i głębokiego osłabienia gospodarczego, wypadkami trudno byłoby wskazać w powojennej historii szkolnictwa wyższego przykłady samoistnego zatrzymania się wzrostu skolaryzacji na poziomie wyższym.

Analizując rozwój szkolnictwa wyższego, należy szczególną uwagę zwrócić na zachowanie dwóch grup aktorów. Pierwszą z nich są zmniejszające bariery w dostępie do wykształcenia szkoły wyższe, a także państwa finansujące i regulujące ich działanie (pytamy wówczas o przyczyny zwiększania się podaży dyplomów); drugą - jednostki inwestujące swój czas, wysiłek i pieniądze w edukację (tu pytanie dotyczy stale rosnącego popytu na wykształcenie). Alternatywą jest spojrzenie na proces umasowienia z perspektywy teorii systemów, badającej ogólny wzrost znaczenia wykształcenia w gospodarce i społeczeństwie, jak w modelu potrójnej helisy (Triple Helix) (Leydesdorff i Meyer 2003; Etzkowitz i Leydesdorff 2000), drugiego modelu produkcji wiedzy (Mode 2 of knowledge production) (Gibbons i in. 1994) czy w perspektywie funkcjonalistycznej (Melosik 2003).

W niniejszym artykule staram się wyjaśnić rozwój systemów szkolnictwa wyższego, przyjmując za punkt wyjścia perspektywę jednostek zdobywających wykształcenie - oznacza to, że kwestia tego, dlaczego uniwersytety (i państwa) tak elastycznie reagują na jednostkowe potrzeby, nie będzie w nim rozważana głębiej, a większość empirycznych przykładów będzie dotyczyć dwóch leseferystycznych systemów szkolnictwa wyższego (USA i Polski), w których przypadki interwencji państwa są relatywnie łatwe do wyizolowania i wyjaśnienia. 
W polskim dyskursie akademickim kwestie związane z uniwersytetem są zazwyczaj analizowane za pomocą języka humanistyki. Humaniści motywację do zdobywania wykształcenia wyższego wyprowadzają z autotelicznej wartości, jaką ma ono posiadać dla jednostek. Edukacja wyższa ma przygotowywać do „bezinteresownego, niespragmatyzowanego, niezinstrumentalizowanego" (Rodziewicz i Rutkowiak 2011) poszukiwania obiektywnej prawdy (Twardowski 1933), ma rozwijać kompetencje krytyczne i zdolność do życia w demokratycznej wspólnocie (Potulicka 2010; Nussbaum 2008), przyczyniając się do harmonijnego rozwoju studenta jako osoby ludzkiej i członka społeczeństwa. Perspektywę tę można dostrzec głównie w myśli krytycznej wobec akademickiej współczesności (do tego nurtu można zaliczyć wszystkie, poza tekstem Twardowskiego, cytowane powyżej źródła). Pełni tam ona rolę normatywnej alternatywy wobec rzeczywistości „neoliberalnego uniwersytetu" i „studenckiego konsumeryzmu” i z tego względu nie daje wglądu w jednostkowe motywacje, ponieważ jej przedmiotem nie jest to, czego studenci chcą od uniwersytetu, tylko to, co mogliby uzyskać, czy też czego, w pojęciu obrońców tradycyjnych form instytucjonalnych akademii, chcieć powinni.

W myśli potocznej ideą równie mocno zakorzenioną (Stankiewicz 2014a), a jednocześnie stojącą w opozycji wobec przekonania o autotelicznej wartości edukacji (Trow 2007) jest utożsamianie edukacji wyższej z przygotowaniem do określonego zawodu. Założenie to leży także u podstaw teorii dryfu akademickiego (Harwood 2010), przeedukowania (Groot i Brink 2000) i większości z wymienianych wcześniej ujęć systemowych, w których edukacja rozważana jest w perspektywie jej społecznej czy gospodarczej funkcji.

Założenie o zawodowym charakterze wykształcenia wyższego, a także skoncentrowane na procesie dopasowywania się edukacji do gospodarki ujęcia funkcjonalistyczne stoją w sprzeczności z rzeczywistymi wyborami studentów umasowionych uniwersytetów. Preferują oni bowiem dyscypliny, których dyplomy są łatwe do zdobycia, ale które albo nie oferują specjalistycznej wiedzy zawodowej (np. socjologia, politologia, filozofia), albo pozwalają pracować w wielu, relatywnie nisko specjalizowanych zawodach (np. pedagogika, zarządzanie), albo w których liczba osób pracujących „w zawodzie” jest ograniczana przez konieczność ukończenia kosztownych kursów dodatkowych lub przedostania się przez „wąskie gardła" kontrolowanej przez korporacje zawodowe selekcji (np. psychologia, prawo). W Polsce studenci tych „miękkich”, niepowiązanych z gospodarką wiedzy dyscyplin stanowili w roku akademickim 2013/2014 60,6\% ogólnej liczby studiujących, a ich absolwenci - 66,7\% wszystkich osób, które ukończyły szkoły wyższe w 2012/2013 r. (GUS 2014b).

${ }^{1}$ Do dyscyplin tych zaliczam stosowane w cytowanym badaniu GUS (i zgodne z Międzynarodową Standardową Klasyfikacją Edukacji, ISCED ‘97) kategorie kierunków: pedagogiczne, artystyczne, humanistyczne, społeczne, dziennikarstwa i informacji, ekonomiczne i administracyjne, prawne, opieki społecznej, usług dla ludności, obrony i bezpieczeństwa. 
Pomimo tego braku specjalizacji (a jest to trend obejmujący wszystkie, za wyjątkiem fińskiego, systemy szkolnictwa wyższego w krajach rozwiniętych; OECD 2014a) dyplomy szkół wyższych zapewniają znaczącą przewagę na rynku pracy. Osoby wykształcone najrzadziej rezygnują z poszukiwania zawodu (w Polsce partycypacja w rynku pracy wynosi ${ }^{2} 79 \%$ dla osób z wyższym wykształceniem i między 54\% a 64\% dla pozostałych grup; GUS 2014c), najczęściej znajdują pracę (stopa ich bezrobocia wynosiła 4,3\%, a dla innych poziomów wykształcenia od $8,8 \%$ do 12,5\%; GUS 2014c) i uzyskują najwyższe zarobki (średnio 2,2 razy większe niż osoby z wykształceniem podstawowym i 1,8 razy większe od osób z wykształceniem średnim wszystkich rodzajów; OECD 2014a).

Wyższe zarobki i większa skłonność do zatrudniania osób wykształconych oznacza, że pracodawcy (niezależnie od często wyrażanego niezadowolenia z kondycji polskich szkół wyższych) uznają dyplom za wyraz kompetencji. Ponieważ większość dyplomów nie sygnalizuje, że ich posiadacz jest specjalistą, natura tych sygnałów nie jest do końca jasna. Mogą one świadczyć o posiadaniu umiejętności „miękkich" i cech osobowości, takich jak solidność, otwartość na nowe doświadczenia, zdolność uczenia się i pracy w grupie (Andrews i Higson 2008; Heckman i Kautz 2012), tendencja do podporządkowania się reżimowi panującemu we współczesnych hierarchicznych i zbiurokratyzowanych organizacjach (Brown 2001) czy predyspozycji do podejmowania długotrwałych zobowiązań, gwarantującej większe przywiązanie pracownika do miejsca pracy (Weiss 1983, za: Lang i Kropp 1986).

Wobec struktury kierunków w umasowionej edukacji i wpływu posiadania dyplomu na sukces na rynku pracy można jako alternatywę dla przekonania o istotności dla studentów autotelicznej wartości edukacji lub jego przydatności w dążeniu do zdobycia określonego zawodu zaryzykować postawienie dwóch tez: po pierwsze, celem większości jednostek nie jest uzyskanie specjalistycznych kredencjałów, pozwalających na wykonywanie określonego rodzaju pracy, tylko kredencjałów uniwersalnych, sygnalizujących posiadanie ogólnych kompetencji przydatnych w szerokiej gamie zawodów; po drugie, główną motywacją do zdobywania dyplomów jest indywidualny interes ekonomiczny, to znaczy wartością, jaka jest brana pod uwagę przez przyszłych studentów i ich rodziny w kalkulacji dotyczącej tego, czy należy, czy nie należy zdobywać wykształcenia, jest zapewniana przez nie przewaga na rynku pracy.

\section{Kredencjały edukacyjne i konkurencja o pracę}

Uznanie, że motywacje do studiowania są jednoznacznie ekonomiczne i że zdobywane przez studiujących kredencjały są uniwersalne, jest dużym uproszczeniem.

${ }^{2}$ Dane z GUS dla 2014 r., z OECD dla 2012 r. 
Empiryczna rzeczywistość szkolnictwa wyższego jest znacznie bardziej złożona. Uproszczenie to pozwala jednak na zobrazowanie powiązań między jednostkami, zdobywanymi przez nie dyplomami i rynkiem pracy w sposób, który może pomóc w zrozumieniu przyczyn jednokierunkowości procesu umasowienia.

Relacje między osobami posiadającymi rozmaite edukacyjne kredencjały (wliczając w to dyplomy ukończenia szkół pierwszego i drugiego stopnia), a dostępnymi miejscami pracy (oferującymi rozmaity poziom płac i społecznego prestiżu) może być, idąc tropem teorii konkurencji o pracę (job competition lub job queue; Thurow 1976), konceptualizowane przez „rozróżnienie pomiędzy dwoma kolejkami. W jednej z nich stoją poszukujący pracy, hierarchicznie uszeregowani zgodnie z posiadanymi kredencjałami. W drugiej znajdziemy miejsca pracy, klasyfikowane w oparciu o ich [atrakcyjność]. Starające się o pracę jednostki dążą do uzyskania najlepszej możliwej pracy, z kolej celem pracodawców jest zatrudnienie najlepiej wykształconych kandydatów" (Wolbers, De Graaf i Ultee 2001). Wynikiem rywalizacji pomiędzy kandydatami o jak najlepsze miejsca pracy i rywalizacji pracodawców o jak najlepiej wykształconych pracowników jest przyporządkowanie jednych do drugich zgodnie z kolejnością, jaką zajmują w odpowiednich „kolejkach”. Ze zdroworozsądkowej perspektywy sytuacja przedstawiona $\mathrm{w}$ tym prostym modelu byłaby optymalna, gdyby każdej posiadającej wyższe wykształcenie osobie przyporządkowany był zawód w pełni wykorzystujący jej umiejętności i zapewniający satysfakcjonujący poziom płac oraz gdyby podobne warunki były spełnione dla wszystkich pozostałych poziomów wykształcenia. W takim wypadku (który wydaje się obrazem społeczeństwa inspirującym teoretyków przeedukowania i dryfu akademickiego) czas i pieniądze zainwestowane w edukację przez każdą jednostkę w doskonale efektywny sposób służyłyby zarówno jej, bez ryzyka zawiedzionych ambicji i zmarnowanych starań, jak i całemu społeczeństwu, które nie przeznaczałoby środków na kształcenie osób niebędących w stanie spożytkować uzyskanej wiedzy w produktywny sposób.

W empirycznie dostępnej rzeczywistości sytuacja optymalnego dopasowania obu kolejek (jeśli wyłączyć całkowicie stabilne systemy społeczne, nieistniejące w Europie od średniowiecza) właściwie nie jest spotykana. Procesy takie jak (i jest to przypadek najczęstszy) poszerzenie dostępu do szkolnictwa wyższego, któremu nie towarzyszy analogiczna zmiana w pozycjach dostępnych w kolejce zawodów (Wolbers i in. 2001), osłabienie gospodarcze zmniejszające liczbę dostępnych miejsc pracy czy zmniejszenie popytu na wysoko wykwalifikowanych pracowników (Beaudry, Green i Sand 2013) powodują, że liczba osób wykształconych przekracza liczbę miejsc pracy, w których ich wykształcenie może być spożytkowane. Ci, którzy przegrają konkurencję o te miejsca, będą starali się zdobyć pracę w zawodach wymagających mniejszych kompetencji, w których pracowały dotąd osoby dysponujące słabszymi kredencjałami i - przy założeniu, że pracodawcy preferują lepiej wykształconych pracowników - miejsca te zdobędą, spychając osoby, które z nimi 
przegrały, na jeszcze niższe pozycje, gdzie proces konkurencji rozpocznie się od początku, obejmując coraz niższe klasy społeczne, a w końcu całe społeczeństwo. W efekcie nawet niewielkie niedopasowanie między liczbą najlepiej wykwalifikowanych pracowników i najlepszych miejsc pracy wyzwala proces, którego efektami są ogólnospołeczna inflacja dyplomów i przeedukowanie. Absolwenci słabszych uniwersytetów zajmują miejsca, które jeszcze pokolenie wcześniej można było zdobyć, dysponując dyplomem ukończenia szkoły drugiego stopnia, absolwenci liceów są wypierani z szeregów klasy średniej, a osoby nieposiadające żadnego wykształcenia poza podstawowym zasilają szeregi bezrobotnych.

Proces ten mógłby się zatrzymać po pojedynczej fazie kaskadowej restrukturyzacji sposobu, w jaki dopasowani są do siebie potencjalni pracownicy i miejsca pracy, gdyby nie reakcja jednostek wypychanych z dotychczasowych nisz zawodowych i w konsekwencji zagrożonych deklasacją. W wypadku najbardziej rozpowszechnionego impulsu wyzwalającego proces umasowienia - gdy gwałtownie (jak w USA w latach 40., Europie w latach 60. czy Polsce w 90. XX wieku) zmniejszają się koszty (finansowe czy intelektualne) edukacji wyższej, a istnieją grupy dostatecznie wykształcone (tzn. posiadające dyplomy liceów), by związaną z tym szansę wykorzystać, zagrożenie deklasacją dotyczy zarówno klasy średniej i niższej, do których zgodnie z opisanym wyżej procesem konkurencja „spływa” kaskadowo z góry, jak i klasy wyższej, zazwyczaj już dobrze wykształconej i zmuszonej poradzić sobie z pojawieniem się konkurencji ze strony edukacyjnych „nuworyszy”. Obie te grupy reagują podobnie: defensywnie zwiększając wydatki edukacyjne, tak by zapobiec deklasacji własnej lub swoich dzieci (Davies, Heinesen i Holm 2002; Goldthorpe 1996). Proces ten przebiega nieco inaczej w przypadku osób, które zajmowały dotąd najwyższe stanowiska, i tych, które próbują obronić się przed wypchnięciem z klasy średniej lub zepchnięciem w szeregi podklasy. Starania tych dwóch ostatnich grup - odbierane jako próba dopasowania się do rosnących wymagań edukacyjnych rynku pracy - stale poszerzają zakres umasowienia, zwiększając współczynnik skolaryzacji na poziomie wyższym i stanowiąc napęd ekstensywnego rozwoju sektora szkolnictwa wyższego. Z kolei starania klas wyższych (opisywane przez Pierre’a Bourdieu jako „ucieczka do przodu”) powodują rozwój intensywny - hierarchizację szkolnictwa i tworzenie selektywnych szkół elitarnych. W efekcie klasy dominujące są zmuszane do inwestowania coraz większej ilości czasu, pieniędzy i wysiłku w rozwój u siebie i swoich dzieci „mierzalnych zalet” (measurable virtue; Stevens 2009), mających zapewnić im przewagę nad konkurencją w wyścigu o najwyższe stanowiska w gospodarce i władzach państwowych. O ile rozwój ekstensywny natrafia na naturalne granice w momencie, gdy wszyscy, którzy są do tego zdolni, zdobywają taki lub inny rodzaj wyższego wykształcenia, o tyle rozwój intensywny - w odpowiednich warunkach - może postępować bez końca, przyjmując formę edukacyjnego wyścigu zbrojeń. Logika intensywnego rozwoju systemu szkolnictwa wyższego wymaga szerszego omówie- 
nia, najpierw należy jednak podsumować dotychczasowe wnioski i odnieść się do najczęściej formułowanego wobec nich zarzutu.

Przy przyjęciu kilku założeń co do motywacji kandydatów na uczelnie wyższe i ich przyszłych pracodawców (założeń upraszczających rzeczywistość empiryczną, ale biorąc pod uwagę dostępne dane nie całkiem nierealistycznych) możliwe jest wyjaśnienie stałego postępu umasowienia jako konsekwencji dążenia kolejnych grup ludzi do uniknięcia deklasacji, jaka zagraża im w wypadku przegrania konkurencji o pracę z lepiej wykształconymi, ale (z różnych względów) niemogącymi w pełni zrealizować swoich ambicji rywalami. Nawet niewielkie z początku przeedukowanie prowadzi do inicjacji kaskadowego procesu, którego efektem jest ekstensywny rozrost systemu szkolnictwa wyższego. Jedyną granicą dla tego procesu jest niemożność poniesienia przez pewien odsetek jednostek intelektualnego lub materialnego kosztu zdobycia wykształcenia, przy czym w systemach opartych na zasadach wolnorynkowych (a takie właśnie istnieją zarówno w Polsce, jak i w USA), komercyjne szkolnictwo ma silną motywację, by dopasować się nawet do potrzeb tych potencjalnych studentów, którzy mają - z punktu widzenia finansów czy zdolności - najmniej do zaoferowania. Należy zauważyć, że w opisywanym powyżej procesie jednostki są pozbawione możliwości dokonania wolnego wyboru drogi edukacyjnej. Nagła zmiana ich otoczenia stawia je przed alternatywą: zwiększenia edukacyjnych wysiłków lub deklasacji. W efekcie edukacja wyższa, będąca kiedyś przywilejem, ewoluuje najpierw w obywatelskie prawo, a w końcu - w bezwzględny przymus (Trow 2007).

Wydaje się, i można to uznać za zarzut wobec formułowanego powyżej modelu, że proces kaskadowej inflacji dyplomów powinien zatrzymać się na poziomie robotników wykwalifikowanych - hydraulików, stanowiących ulubioną figurę krytyków umasowienia zarówno w Polsce, jak i za oceanem, trudno zastąpić absolwentami słabych liceów. W związku z tym powinna istnieć grupa osób, która zyskałaby na ograniczeniu raczej niż eskalacji swoich edukacyjnych ambicji. U podstaw tej intuicji (formułowanej często zarówno w dyskursie akademickim, jak i publicznym) leży brak świadomości co do stopnia deindustrializacji współczesnych gospodarek i rzeczywistej sytuacji finansowej osób o wykształceniu zawodowym. W Polsce jest to grupa znajdująca się w najgorszej (jeśli nie liczyć osób posiadających jedynie wykształcenie podstawowe/gimnazjalne) sytuacji materialnej. W obejmującym 18 krajów badaniu poziomu płac i zatrudnienia osób z wykształceniem ogólnym i zawodowym Eric A. Hanushek, Ludger Woessmann i Lei Zhang (2011) wykazali, że absolwentom szkół zawodowych łatwiej było znaleźć pracę tuż po ukończeniu edukacji, ale dużo wcześniej niż absolwenci szkół o profilu ogólnokształcącym (liceów i uniwersytetów) opuszczali oni rynek pracy, co częściowo tłumaczy przewagę płacową tej ostatniej grupy. Polska była jedynym wśród badanych krajów, w którym poziom zatrudnienia był dla absolwentów szkół o profilu ogólnym wyższy w każdej kategorii wiekowej. Wyższe też, choć z począt- 
ku nieznacznie, były pensje młodych pracowników z wykształceniem akademickim (Herbst i Sobotka 2014). Problem osób nieposiadających kredencjałów szkół wyższego stopnia polega na tym, że o ile w systemie umasowionego czy wręcz zuniwersalizowanego szkolnictwa wyższego dyplom uniwersytetu słabiej niż kiedyś sygnalizuje kompetencje, o tyle jego nieposiadanie staje się wyraźnym sygnałem ich braku (Hämäläinen i Uusitalo 2008; Stankiewicz 2014b). Próba uniknięcia inflacji dyplomów przez „zdobycie zawodu” z dużym prawdopodobieństwem zakończy się więc niepowodzeniem, a przynajmniej relatywną stratą. Sytuacja wygląda podobnie w USA, gdzie praca fizyczna jest zarezerwowana dla imigrantów (Peri i Sparber 2008), a absolwenci uniwersytetów rywalizują z absolwentami liceów o niewymagające kwalifikacji, ale mniej uciążliwe stanowiska („baristów i pracowników biurowych"; Beaudry i in. 2013). Ostatecznym efektem tego procesu jest wypchnięcie osób z wykształceniem średnim na pozycje zależnej od pomocy społecznej podklasy i powstanie, większej niż kiedykolwiek wcześniej, przepaści finansowej pomiędzy tymi dwiema grupami (Taylor, Fry i Oates 2014).

Opisane wyżej mechanizmy pokazują nie tyle sprawczość jednostek, ile mechanizm jej ograniczania - sposób, w jaki wolny wybór ścieżki edukacyjnej jest dyktowany przez mechanizmy konkurencji o miejsce w społecznej hierarchii. Sytuację, w której grupa jednostek, kierując się interesem własnym (pragnieniem uzyskania awansu czy uniknięcia degradacji klasowej), generuje ogólnospołeczny „przymus” edukacyjny, można opisać za pomocą kategorii „społecznej pułapki”. Zanim zajmę się jej opisem, dokonam analizy drugiego przejawu umasowienia - rozwoju intensywnego, który w przeciwieństwie do poszerzania dostępu do wykształcenia nie ma żadnych wyraźnych granic i przyjmuje w swoim przebiegu cechy pozycjonalnego wyścigu zbrojeń.

\section{Rozwój intensywny i edukacyjne wyścigi zbrojeń}

Istnieje różnica w sposobie, w jaki dokonuje się zwiększanie edukacyjnych nakładów przez jednostki „doganiające” czołówkę edukacyjnego peletonu a tymi, które znajdując się na przedzie, „uciekają” przed oddolną presją konkurencyjną. Pierwsza z tych grup podąża ubitymi drogami, starając się zdobyć uznane już kredencjały lub ich imitacje, druga natomiast wymusza na systemie edukacyjnym ciągłą zmianę, uciekając z nisz zagrożonych przez inwazję studentów „masowych”, separując się w edukacyjnych fortecach szkół elitarnych, delegitymizując zagrażające jej kredencjały pośledniejszego rodzaju, wreszcie redefiniując kryteria wartościowania, i modyfikując obowiązujące w danej kulturze wzorce osobowe (Karabel 2005; Bourdieu 2005), tak by utrudnić zadanie starającej się ją naśladować konkurencji.

Instytucjonalnym wyrazem intensywnego rozwoju szkolnictwa wyższego jest istnienie na wszystkich poziomach szkolnictwa sektorów elitarnych (ich wzorcowe 
przykłady można odnaleźć we Francji, USA i Wielkiej Brytanii). Sektory te pozwalają wąskiej grupie ludzi na ucieczkę przed logiką rozwoju ekstensywnego i inflacją dyplomów. Dobrem, które szkoły elitarne oferują swoim klientom, jest nieobciążony przez związki z masowymi „fabrykami dyplomów” edukacyjny prestiż, a instytucjonalną własnością pozwalającą im wytwarzać to dobro jest ekskluzywność (Marginson 2007), to znaczy możliwości odrzucenia podczas procesu rekrutacji większości kandydatów. Elitarna selektywność jest właściwością działającą na zasadzie dodatniego sprzężenia zwrotnego. Szkoły są elitarne, ponieważ aplikuje do nich tak wielu kandydatów (z których większość nie jest przyjmowana), a mają tak wielu kandydatów, ponieważ są elitarne (Stankiewicz 2014b). Konieczność prowadzenia selekcji powoduje, że najbardziej prestiżowe szkoły mają ograniczoną wielkość (ponieważ im więcej jest przyjmowanych studentów, tym mniejsza selektywność i w konsekwencji mniejsza elitarność) i nie mogą elastycznie dopasowywać liczby oferowanych miejsc do liczby klientów, ponieważ niedopasowanie tych dwóch wartości czyni je tym, czym są.

Przed rozpoczęciem okresu wzrostu ekstensywnego elitarność szkół wyższych nie wiązała się z merytokratyczną, a społeczną ekskluzywnością. Studiowali w nich młodzi mężczyźni z najbardziej wpływowych rodzin (Karabel 2005; Piketty 2015). $\mathrm{W}$ tym okresie zdobywanie wykształcenia miało w nich często drugorzędne znaczenie. Zapewniały one za to swoim studentom możliwość obcowania z ludźmi podobnie jak oni zamożnymi, budowania sieci kapitału społecznego i w związku z tym ułatwiały procesy międzypokoleniowego transferu uprzywilejowanej pozycji (Karabel 2005), a także legitymizowały ten proces, wiążąc go z osiągnięciami edukacyjnymi (Piketty 2015).

Proces umasowienia spowodował, że tradycyjni klienci sektora elitarnego zostali zmuszeni do rywalizacji o wstęp do niego z osobami o skromniejszym pochodzeniu. Z początku w wielu krajach „problem” ten wiązał się głównie z osobami pochodzenia żydowskiego i rozwiązywano go, wprowadzając mniej lub bardziej jawne mechanizmy dyskryminacji (Karabel 2005; Graboń 2000). Czyniono to z pełną świadomością, że jej celem jest ograniczenie „bezlitosnej konkurencji o miejsca na uniwersytecie" (Karabel 2005: 115), która byłaby wynikiem stosowania czysto merytokratycznych zasad rekrutacji w czasach, w których rozpoczynał się proces demokratyzacji dostępu do szkolnictwa wyższego.

Dobrym przykładem ewolucji sektora elitarnego są najbardziej selektywne koledże Stanów Zjednoczonych, ze względu na swój prywatny charakter dysponujące znacznie większą swobodą działania niż szkoły we Francji czy Wielkiej Brytanii. W ciągu kilku powojennych dekad otwierały się one stopniowo na dyskryminowane wcześniej grupy społeczne - kobiety, czarnych i Żydów (Karabel 2005). Nasilona konkurencja, która miała wiązać się z usunięciem mechanizmów dyskryminacji, została z początku stłumiona przez długotrwałą stagnację gospodarczą lat 70. $\mathrm{XX}$ wieku i związane z nią zahamowanie dynamiki wzrostu rekrutacji. Konkuren- 
cja nabrała siły w kolejnych dekadach, gdy szybkiemu wzrostowi gospodarczemu towarzyszyło gwałtowne zwiększenie się nierówności płacowych i majątkowych (Piketty 2015) oraz kształtowanie się systemu społeczno-gospodarczego, w którym - w porównaniu z okresem powojennym - zwycięstwa były lepiej wynagradzane (winner takes-all society; Frank i Cook 1995; Frank 2000), a porażki karane, co jednocześnie zmniejszało liczbę miejsc na szczycie drabiny zawodów i czyniło je bardziej lukratywnymi niż kiedykolwiek. Zmianom tym towarzyszyło szybkie umasowienie i ogólnospołeczny wzrost wydatków edukacyjnych. Ponieważ mniej zamożne klasy częściej zdobywają edukację w słabszych, nieprowadzących intensywnej selekcji szkołach, dwuletnich community colleges czy wielkich uniwersytetach komercyjnych - przyczyniając się do ekstensywnego rozwoju systemu szkolnictwa wyższego, ale tylko incydentalnie biorąc udział w konkurencji o miejsca na samym szczycie - dynamika wzrostu ich wydatków była znacznie mniejsza niż dla będącej tradycyjnym klientem szkół elitarnych wyższej klasy średniej. Ta ostatnia, angażując swoje dzieci w „wyścig szczurków” (rug rat race; Ramey i Ramey 2009), w którym coraz większa liczba uczestników rywalizuje o niezmienną od dekad liczbę dyplomów (Bound i Turner 2007), dostała się w błędne koło wydatków. Konkurencja obejmująca zamożne rodziny (i najzdolniejsze dzieci z mniej zasobnych domów, choć te w sumie zajmują tylko 30\% miejsc w najbardziej selektywnych szkołach; Century Foundation 2013) z każdym rokiem wyżej podnosi poprzeczkę wydatków i wysiłków koniecznych do przedostania się przez rekrutacyjne sito. Ze względu na specyfikę procesu rekrutacji w elitarnych szkołach USA (Karabel 2005) - oceniających kandydatów nie tylko na podstawie osiągnięć akademickich, ale również „zdolności przywódczych” i aktywności pozaszkolnej - konkurencja o wstęp nie ma wyłącznie wymiaru edukacyjnego, ale wymaga organizowania całego życia dzieci i nastolatków pod kątem pożądanych przez szkoły cech (Bound, Hershbein i Long 2009a). W efekcie w ciągu 30 lat dzielących lata 70. i pierwszą dekadę XXI wieku, pozaszkolne wydatki przeznaczone na edukację i rozwój dzieci rosły, dla amerykańskich rodzin z dochodem w górnym kwartylu, trzykrotnie szybciej niż dla rodzin w kwartylu dolnym (Duncan i Murnane 2011). W tym samym okresie różnica między czasem spędzanym z dziećmi (głównie dziećmi starszymi) przez matki z wykształceniem wyższym i te nieposiadające dyplomów z koledży wzrosła od zera (w 1975 r.) do czterech godzin tygodniowo (w 2005 r.). Wykształcone matki spędzają z dziećmi 2/3 więcej czasu niż w latach 70. i 1/5 więcej niż matki bez wykształcenia wyższego (Ramey i Ramey 2009). Podobny wzorzec jest widoczny w ilości czasu przeznaczanego na naukę. Wzrósł on w ostatnich dekadach dla wszystkich, ale największa dynamika wzrostu dotyczyła licealistów starających się o przyjęcie do selektywnych szkół wyższych (Bound, Hershbein i Long 2009b). Dodatkowym czynnikiem zwiększającym koszty ponoszone przez studentów i ich rodziny jest postępowanie samych uniwersytetów, które wykorzystując to, że ich klienci są skłonni sporo zapłacić za wstęp, i motywowane tym, że ich pozycja w pu- 
blikowanych przez media tabelach ligowych zależy od wysokości ich wydatków na nauczanie, nieustannie zwiększają czesne. Od lat 70. XX wieku wzrosło ono, jeśli weźmie się pod uwagę inflację, ponad trzykrotnie (Stankiewicz 2014a).

Zwiększanie nakładów, dokonywane w celu prześcignięcia konkurencji, która równolegle i w tym samym celu zwiększa własne nakłady, rządzi się logiką „wyścigu zbrojeń”. Nadmierne inwestycje jednej ze stron napędzają nadmierne inwestycje drugiej w nieskończonym sprzężeniu zwrotnym generującym koszty niewspółmierne do ostatecznego efektu (Hirsch 2005; Frank 2005). Dynamika wzrostu wydatków pozaszkolnych, czasu spędzanego z dziećmi i cena, jaką są w stanie dyktować swoim klientom uniwersytety, a także trudniejsze do skwantyfikowania zmiany w światopoglądzie, motywacjach i zachowaniach wyższej klasy średniej - przedostawanie się elementów edukacyjnych i związanej z nimi motywacji (czy przymusu) stałego indywidualnego rozwoju do coraz nowych dziedzin życia, a także traktowanie własnego rozwoju jako broni w nieustannej konkurencji o prestiż i pozycję - są bezpośrednim wynikiem tego wyścigu (Ramey i Ramey 2009; Bound i in. 2009; Stevens 2009; Friedman 2013). Wyższa klasa średnia, podobnie jak klasy znajdujące się niżej w społecznej hierarchii, i w wyniku oddziaływania podobnych mechanizmów, pozbawiona jest wyboru przez logikę rozwoju umasowienia. Uciekając przed konsekwencjami jednej pułapki społecznej, wpada w kolejną.

Polskie doświadczenie umasowienia różni się od amerykańskiego tym, że instytucjonalne i finansowe warunki panujące w okresie gwałtownego rozwoju systemu szkolnictwa wyższego wymusiły na uniwersytetach, włączając w to najstarsze i najbardziej prestiżowe placówki, znaczne zwiększenie naborów (Kwiek 2010). Wiodące polskie uniwersytety są pod względem liczby przyjmowanych studentów zbliżone do całych sektorów elitarnych większych od Polski krajów, takich jak Wielka Brytania czy Francja. Roczny nabór do Uniwersytetów Warszawskiego i Jagiellońskiego jest niewiele mniejszy niż ten dokonywany przez całą Ligę Bluszczową, skupiającą najbardziej prestiżowe uniwersytety ośmiokrotnie od Polski ludniejszych Stanów Zjednoczonych (Stankiewicz 2014b). Elitaryzacja wiodących placówek wymagałaby nie tylko niezwiększania, ale wręcz ograniczenia przez nie naboru - co wobec ciągle złożonej finansowej i prawnej sytuacji sektora szkolnictwa wyższego było zadaniem niemożliwym do wykonania. Oznacza to, że choć rozwój ekstensywny wytworzył - zgodnie z opisywanym wcześniej mechanizmem - potrzebę „ucieczki do przodu”, to nie powstały instytucjonalne mechanizmy jej zaspokojenia. Popyt na edukacyjny prestiż znajduje drogi ujścia w ramach elitarnych szkół podstawowych czy liceów (Mikiewicz 2005), ale nie kończy się „»ukoronowaniem « edukacyjnej ścieżki dziecka przez umieszczenie go w elitarnej szkole wyższej”, ponieważ tych w Polsce nie ma (Stankiewicz 2014b: 122).

Intensywny rozwój szkolnictwa wyższego w Polsce przyjmuje formy mieszczące się w istniejącej architekturze instytucjonalnej. Jego przejawem jest akumula- 
cja przez jednostki różnych kredencjałów, zdobywanie dyplomów wielu kierunku studiów, kończenie szkół podyplomowych lub studiów doktoranckich, kursów językowych i szkolen - stała pogoń za uzyskaniem doświadczenia zawodowego dzięki wolontariatowi i darmowym stażom, a także - co stanowi podstawowy, choć kosztowny sposób na uzyskiwanie edukacyjnego prestiżu w krajach peryferyjnych - studiowanie za granicą (Marginson 2007). Można zakładać, że brak elity uniwersytetów, których wymagania podczas procesu rekrutacji pozwalają klasom wyższym zdefiniować znaczenie edukacyjnego sukcesu i porażki, zwiększa ryzyko, że te różnorodne inwestycje edukacyjne nie będą relewantne dla przyszłej ścieżki zawodowej. Efektem ubocznym takiego stanu rzeczy jest istnienie powszechnego przekonania o dużym znaczeniu odgrywanym podczas poszukiwania pracy przez negatywnie oceniany kapitał społeczny („znajomości”; Sadowski 2012). Ten ostatni ma również ogromne znaczenie w systemach, w których elitarne szkoły funkcjonują (Golden 2006), ale jego wpływ jest za ich pomocą ukrywany i dopasowywany do merytokratycznych standardów współczesnych społeczeństw.

Ekstensywny rozwój systemu szkolnictwa wyższego jest tożsamy z powszechnym rozumieniem słowa „umasowienie”. Rozwój intensywny, różnicujący rynek szkół wyższych i generujący edukacyjne wyścigi zbrojeń, jest znacznie słabiej rozpoznany, zarówno w ramach dyskursu akademickiego, jak i publicznego, w których „umasowienie” jest zazwyczaj kojarzone wyłącznie ze wzrostem liczby dyplomów i związanym z tym spadkiem ich wartości. Ponieważ rozwój intensywny pozwala pewnej części populacji na ucieczkę od problemów wywołanych demokratyzacją szkolnictwa wyższego, zinstytucjonalizowanie go (przez stworzenie sektora elitarnego) jest często przedstawiane nie jako „kontynuacja umasowienia innymi środkami”, ale jako recepta na związane z nim patologie (Stankiewicz 2014a).

W rzeczywistości wartość szkół elitarnych jest wysoce niejednoznaczna. Ze względu na ostre kryteria selekcji trudno odróżnić ich edukacyjny wkład i wpływ tego wkładu na (zazwyczaj nieuchronny) sukces życiowy ich absolwentów od efektu „zbierania śmietanki” (Whitty 1997; Dale i Krueger 1999), efektu rówieśników (peer effect; Winston 1999; Dolata 2014) czy znaczenia uzyskanego w szkole kapitału społecznego (Zweigenhaft 1993). Eskalacja wydatków w edukacyjnych wyścigach zbrojeń generuje też znaczne nierówności edukacyjne. Ponieważ niewiele osób jest w stanie za pomocą samych umiejętności rywalizować z przewagą w zakresie kapitału finansowego, kulturowego i społecznego klas uprzywilejowanych, szkoły elitarne, pomimo ich z pozoru merytokratycznej natury, są zdominowane przez dzieci z zamożnych rodzin. Średnia zasobność rodziny studenta Harwardu sytuuje ją wśród 2\%, a francuskiego Sciences Po, 10\% najbogatszych w kraju (Pikkety 2015). W USA różnice w nakładach edukacyjnych doprowadziły do pojawienia się luki w osiągnięciach szkolnych pomiędzy dziećmi najbogatszych i klasy średniej (zazwyczaj luka ta była widoczna pomiędzy dziećmi obu tych klas i dziećmi z biednych rodzin; Reardon 2011). 
Można by przy tym argumentować, że nawet „nieracjonalne” wydatki edukacyjne będą miały pozytywny wpływ na życie jednostek i dobrobyt wspólnoty, jednak porównanie takich parametrów, jak dochód na głowę mieszkańca czy osiągnięcia edukacyjne w stanach USA ze zróżnicowanym poziomem edukacyjnej konkurencji, sugeruje, że dodatni efekt „wyścigów zbrojeń” nie występuje (Bound i in. 2009a; 2009b). To znaczy, że wszystkie wydatki i czas przeznaczany przez przedstawicieli zamożniejszych warstw społecznych na to, by umieścić swoje dzieci w elitarnych szkołach, nie mają żadnego zauważalnego wpływu na jakość i efektywność edukacji - chyba że za główną funkcję szkół elitarnych uzna się maskowanie procesu reprodukcji.

Wyścig o miejsca na szczycie drabiny osiągnięć edukacyjnych, podobnie jak opisywane próby uniknięcia deklasacji przez niższe szczeble klasy średniej, ogranicza indywidualną sprawczość, prowadząc do wytworzenia nieformalnego przymusu edukacyjnego. Kolejna część artykułu dotyczy teorii, za pomocą której można opisać procesy eliminacji jednostkowej sprawczości w obu przedstawionych powyżej formach edukacyjnej ekspansji.

\section{Natura społecznych pułapek}

Specyfiką przejawów umasowienia - rozwoju ekstensywnego i intensywnego których efektami są: stałe zwiększanie współczynnika skolaryzacji w pierwszym i wyścig zbrojeń o uzyskanie ograniczonej liczby miejsc w sektorze elitarnym lub akumulacja rozmaitych kredencjałów w drugim wypadku, jest to, że oba można opisać za pomocą pojęcia „społecznych pułapek”.

Przez społeczną pułapkę rozumiem sytuację, w której podjęte w interesie własnym działanie jednostki modyfikuje rachunek zysków i strat innych jednostek w jej otoczeniu, w taki sposób, że zwiększa się prawdopodobieństwo tego, iż one

${ }^{3}$ Pojęcie „pułapki społecznej” było stosowane w amerykańskiej, akademickiej psychologii lat 70. i 8o. XX wieku (Platt 1973), współcześnie zostało wyparte przez - zbliżone zakresem znaczeniowym - pojęcie „dylematu społecznego” (Dawes 1980), służące do opisu rozbieżności między krótkoterminowym interesem jednostki a długoterminowym wspólnoty, występującym przy zarządzaniu dobrami wspólnymi (common goods) i wytwarzaniu dóbr publicznych (public goods). Sposób, w jaki stosuję je tutaj, wykracza poza oba te użycia. Procesy analogiczne do pułapek społecznych, definiowanych tak jak w tym artykule, są w literaturze ekonomicznej opisywane jako efekt wozu z orkiestrą (bandwagon effect, analogiczny do polskiego określenia: efekt kuli śniegowej; Liebenstein 1950); zachowania stadne (herd behavior; Banerjee 1992) czy sieciowe efekty zewnętrzne (network externalities; Katz i Shapiro 1985). Analogiczne do używanego tutaj jest pojęcie „pułapek społecznych” wykorzystywane w ramach kognitywnej teorii gier (Scharpf 1997; Rothstein 2005). Wykorzystanie tej ostatniej jest utrudnione złożonością problematyki, niejasnościami definicyjnymi i jej relatywną nieobecnością w dyskursie polskich nauk społecznych. Z tego względu zdecydowałem się na wprowadzenie własnej, uproszczonej, definicji pułapek społecznych. 
również podejmą dane działanie. O społecznych pułapkach możemy mówić, gdy jakiś rodzaj działania rozprzestrzenia się w społeczeństwie na zasadzie kuli śniegowej (czy efektu wozu z orkiestrą) - jednostki włączając się w nie, przyciągają do niego kolejne jednostki. Każda osoba, decydując się „wpaść” w pułapkę, nieświadomie generuje efekty zewnętrzne (externalities; Katz i Shapiro 1985), które oddziałują na wszystkich innych, a ostatecznie, za sprawą sprzężenia zwrotnego, również na nią samą. Przykładami tak rozumianych pułapek społecznych mogą być bańki spekulacyjne (Shiller 2002), wyścigi zbrojeń (Frank 2011), funkcjonowanie sieci telefonicznych (Katz i Shapiro 1985) i społecznościowych (Stankiewicz 2014b), cykle mody (Morgenstern 1948; Liebenstein 1950), korupcja (Rothstein 2005), a także umasowienie edukacji (Hirsch 2005; Frank 2000).

Tak zdefiniowane pułapki niekoniecznie są - ze społecznego i jednostkowego punktu widzenia - groźne. W niektórych wypadkach, takich jak rozwój sieci telefonicznych czy społecznościowych, każda dołączająca się do grupy osoba zwiększa korzyść, jaką wszyscy inni uzyskują, pozostając w sieci lub przyłączając się do niej. Nawet w takiej sytuacji proces ten może mieć negatywne konsekwencje, np. dany produkt może wygrać konkurencję nie dlatego, że jest lepszy, ale że jako pierwszy zdominował rynek, powodując, iż przyjęcie bardziej efektywnych (ale później odkrytych) rozwiązań stało się zbyt kosztowne (David 1985). Edukacji (a także militarnych wyścigów zbrojeń i mody) dotyczy inny - znacznie poważniejszy problem, wynikający z tego, że posiada ona cechy dobra pozycjonalnego (Hirsch 2005; Frank 2011). W wypadku dóbr pozycjonalnych cały lub większość czerpanego z nich pożytku wynika z posiadania ich w większej ilości lub lepszej jakości niż inni konsumenci (Stankiewicz 2014b). Edukacja niewątpliwie jest dobra sama w sobie, ale jeśli jej posiadanie służy nam do uzyskiwania przewagi na rynku pracy czy dóbr symbolicznych i poprawia naszą społeczną pozycję (a głównie tych pożytków z niej dotyczy ten artykuł), to nie da się orzec, czy jest „dobra”, czy „zła”, nie odpowiadając jednocześnie na pytanie o to, jaką edukację zdobyli nasi rywale.

Absolwent liceum nie znajduje się współcześnie w sytuacji gorszej niż jego przedwojenny odpowiednik wyłącznie dlatego, że jego edukacja jest niższej próby. Główną przyczyną jego problemów na rynku pracy jest to, że posiadany przez niego kredencjał w żaden sposób nie odróżnia go od większości jego rówieśników. Nawet gdyby zdobył edukację na „przedwojennym” poziomie, i tak przegrałby rywalizację z każdym, kto zdobył wykształcenie wyższe. Relatywna pozycja ma więc dla wykształcenia większe znaczenie niż jego absolutny poziom (Stankiewicz 2014b).

Społeczne pułapki powstałe wokół dóbr pozycjonalnych wiążą się z potencjalnym marnotrawstwem, ponieważ rywalizacja o te dobra jest - z powodu ich specyficznej natury - grą o sumie zerowej. Tak jak w wypadku wyścigu sportowego nie istnieje możliwość, by zdobyć pozycję, nie powodując jednocześnie, że ktoś pozycję straci. To znaczy, że wszystkie wydatki na dobra pozycjonalne nie są w stanie wygenerować ogólnospołecznego zysku, a co najwyżej doprowadzić do redystrybu- 
cji prestiżu i pozycji między członkami wyścigu. Każdy posiada indywidualną motywację, by dokładać starań mających na celu uzyskanie pozycji kosztem innych lub przynajmniej nie utracić jej na rzecz swoich rywali, ale z perspektywy całego społeczeństwa te indywidualnie racjonalne wysiłki nie przyczyniają się do powstania jakiejkolwiek wymiernej zmiany. Środki przeznaczone na rywalizację można uznać za zmarnowane, szczególnie w (dość często spotykanej) sytuacji, w której równoczesne i proporcjonalne zwiększanie nakładów powoduje, że relatywna pozycja wszystkich aktorów wyścigu się nie zmienia. Paradygmatycznym przykładem takiej sytuacji jest rywalizacja militarna:

W czasie wyścigu zbrojeń państwo może uzyskać przewagę nad swoim rywalem, produkując większą ilość uzbrojenia. Wywołuje to reakcję jego przeciwnika, który by przywrócić równowagę, sam zaczyna się zbroić. W wyniku kolejnych faz reakcji i kontrreakcji oba państwa wydają znaczną część swojego dochodu, [ale] żadne z nich nie jest bardziej bezpieczne niż było, nim zbrojenia się rozpoczęły. [...] Istnieje prawie powszechna zgoda co do tego, że proces ten wiąże się z marnotrawstwem. Oba państwa zyskałyby więcej, wydając mniej pieniędzy na broń, a więcej na szkoły, mieszkania, szpitale, drogi i inne dobra przydatne cywilom (Frank 2011: 64).

W pułapkach społecznych opartych na rywalizacji o dobra pozycjonalne mamy do czynienia z przykładem rozbieżności między racjonalnością indywidualną a grupową (Rothstein 2005). Gdyby sytuacja wyścigu była przez jednostki obserwowana spoza „zasłony niewiedzy” (Rawls 2009) - to znaczy gdyby miały one zadecydować o preferowanym stanie świata społecznego, bez utożsamiania się w którymkolwiek z aktorów systemu - wówczas preferowałyby świat, w którym do wyścigu nie dochodzi. Ta preferencja światów potencjalnych, ale niezrealizowanych nie pojawia się zresztą tylko w ramach analiz filozoficznych, ale zdaje się być nieusuwalną cechą realnych pułapek społecznych. Tkwiący w nich aktorzy zdają sobie sprawę z istnienia alternatyw zaistniałego stanu, ale ponieważ ich własne decyzje są uzależnione od decyzji wszystkich innych aktorów systemu, nie są oni w stanie podjąć działań, które doprowadziłyby do zmiany społecznej.

Opis struktury pułapki społecznej i sprzecznych motywacji konstytuujących ją aktorów można odnaleźć już w napisanym prawie cztery wieki temu Lewiatanie Thomasa Hobbesa (2009). Pułapką jest tu stan natury, permanentna wojna wszystkich ze wszystkimi, czyniąca ludzkie życie „samotnym, biednym, pozbawionym słońca, zwierzęcym i krótkim" (Hobbes 2009: 207). Aktorzy zdają sobie sprawę z możliwości zaistnienia lepszych światów społecznych, pod warunkiem że przestrzegane byłyby Hobbesowskie prawa natury mówiące, że szacunek wobec własności, dotrzymywanie umów, okazywanie wzajemności i wdzięczności swoim bliźnim pozwoli wspólnocie na prowadzenie pokojowego i owocnego życia. Pomimo powszechności wiedzy o istnieniu alternatyw stanu wojny nikt nie jest $\mathrm{w}$ stanie wykonać kroku w kierunku lepszego świata: 
Prawa natury obowiązują in foro interno (na forum wewnętrznym); to znaczy obowiązują one do pragnienia, by tak było, jak one mówią; natomiast nie zawsze obowiązują in foro externo (na forum zewnętrznym), to znaczy nie zawsze obowiązują do tego, by je wprowadzać w czyn. Człowiek bowiem, który byłby skromny, uprzejmy i który by dopełniał wszystkich swoich przyrzeczeń w takim czasie i miejscu, gdzie żaden inny człowiek tego nie czyni, wystawiałby się tylko na pastwę innych ludzi i sprowadziłby pewną swoją zagładę, co by było sprzeczne z podstawą wszelkich praw natury" (Hobbes 2009: 241).

Hobbesowska analiza pokazuje, w jaki sposób patologiczne systemy mogą w całości składać się z aktorów posiadających „dobre” intencje, ale ograniczonych w swojej zdolności do działania przez wybory dokonywane przez innych członków wspólnoty. Paradoks tej sytuacji polega na tym, że system może długo pozostawać w takim „suboptymalnym stanie równowagi” (Rothstein 2005), nawet jeśli dokładnie wszyscy składający się na niego aktorzy są ludźmi skłonnymi do przestrzegania norm społecznego zachowania. Jednostki są nakłaniane do zachowań kolektywnie nieracjonalnych przez „system” konstytuowany w całości przez decyzje innych jednostek. Każdy „nadzoruje” każdego, zakładając jednocześnie, że zachowałby się „dobrze”, gdyby wszyscy inni tak się zachowywali, a ponieważ wszyscy są dokładnie w tej samej sytuacji, do zmiany nigdy nie dochodzi.

Opuszczenie pułapki społecznej nie jest zadaniem łatwym. Hobbes argumentował, że konieczne jest wykorzystanie mechanizmów nacisku, jakimi obdarzona jest suwerenna władza. Ta jednak sama często bywa źródłem problemów, a działający w jej strukturach aktorzy są równie bezsilni (czy niegodni zaufania) jak reszta populacji (Rothstein 2005).

Zarówno intensywny, jak i ekstensywny rozwój szkolnictwa wyższego posiada cechy społecznej pułapki. W obu wypadkach aktorzy są zmuszani do działania przez postrzeganą zmianę warunków panujących w ich otoczeniu społecznym, a ich reakcja przyczynia się do pogłębienia tej zmiany, wciągając do wyścigu nowych aktorów (w wypadku rozwoju ekstensywnego) lub wymuszając nasilenie wysiłków na tych, którzy już biorą w nim udział. Działanie aktorów jest z ekonomicznego punktu widzenia racjonalne i posiadają oni sprawczość - ich wybory determinują kształt całego systemu, ale ich wolność do wyboru własnej drogi życiowej jest drastycznie ograniczana, tworząc nieformalny przymus zdobywania wykształcenia wyższego.

\section{Podsumowanie - pułapki społeczne i wartość wykształcenia}

Analiza umasowienia za pomocą użyciu teorii społecznych pułapek pozwala na zrozumienie roli jednostkowej sprawczości we współzależnych procesach demokratyzacji i elitaryzacji szkolnictwa wyższego. Aktorzy społeczni - wbrew twierdzeniom wielu przeciwników umasowienia - działają, z ekonomicznego punktu 
widzenia, w pełni racjonalnie, co nie gwarantuje jednak wytworzenia rozwiązań zgodnych z interesem konstytuowanej przez nich społeczności. Z tego względu główny wniosek, jaki można wyciągnąć z analizy społecznych pułapek, dotyczy istotności instytucji społecznych i kształtujących je działań kolektywnych, które powinny łagodzić skutki niedającej się usunąć z edukacji sprzeczności między interesem indywidualnym a zbiorowym. Odnosząc się do, podobnie jak edukacja, podatnej na logikę społecznych pułapek kwestii obywatelskiego zaangażowania, Bo Rothstein pisal:

[...] ciężar odpowiedzialności nie powinien spoczywać na barkach obywateli [...] ale systemu politycznego i politycznych elit. [...] to rządy ponoszą odpowiedzialność za niski poziom „kapitału społecznego" z powodu własnej niezdolności do stworzenia godnych zaufania instytucji (Rothstein 2005: 27).

W wypadku edukacji wyższej, tam gdzie wielu jej krytyków jest skłonnych widzieć irracjonalność mas niszczących zastane instytucje, mamy w rzeczywistości do czynienia z jednostkową racjonalnością, kanalizowaną przez ułomne instytucje w potencjalnie destruktywny z perspektywy dobra ogółu sposób.

To, że systemy edukacyjne mogą, w zderzeniu z ambicją aktorów, generować rozwiązania niesatysfakcjonujące nikogo, wynika z pozycjonalnej natury dóbr, które się za ich pomocą uzyskuje. Kwestią dotąd nieporuszaną jest to, że edukacja posiada również wartość niepozycjonalną. To, czy instytucje powinny być kształtowane w sposób, który pozwala na nieograniczone umasowienie, czy nieograniczone „pogłębianie” systemu przez jego elitaryzację, powinno zależeć od rachunku zysków i strat wiążących się z oboma uzyskiwanymi w procesie wykształcenia rodzajami dóbr. Kalkulacja taka nie jest łatwa do przeprowadzenia, głównie z tej przyczyny, że decyzje odnoszące się do systemu edukacyjnego są też decyzjami dotyczącymi pożądanego kształtu społeczeństwa w ogóle, co oznacza, że należą one do niepoddającego się ilościowej analizie reżimu polityczności. Gdyby jednak opierać się na możliwych do skwantyfikowania danych, należałoby stwierdzić, że w wypadku klasycznie pojmowanego umasowienia (nazywanego tu rozwojem ekstensywnym) zyski wydają się dominować nad stratami. Co prawda całe społeczeństwo, w wyniku opisanych w artykule kaskadowych procesów konkurencji o pracę i pozycję społeczną, jest zmuszane do ponoszenia wydatków, które w ostatecznym rozliczeniu nie zaburzają istniejących hierarchii ani nie lagodzą nierówności, jednak samo zdobycie edukacji wyższej posiada wiele dobrze udokumentowanych pozytywnych konsekwencji w tak zróżnicowanych obszarach ludzkiego życia, jak: zdrowie (Wróblewska 2010), partycypacja wyborcza (Cześnik 2009), partycypacja w społeczeństwie obywatelskim (OECD 2014a), długość życia (OECD 2014b), stabilność związków małżeńskich (Hout 2012) czy ekonomiczna produktywność (Goldin i Katz 2009). W przeciwieństwie do tradycyjnie rozumianego umasowienia, rozwój intensywny - podporządkowany logice walki o społeczną supremację 
i reprodukcję przywileju - jest w zasadzie ograniczony do swojego składnika pozycjonalnego. Jak wspominałem wcześniej, mimo ogromnych kosztów i konieczności kształtowania całej drogi życiowej w zgodzie z determinowaną przez niego logiką nie wydaje się on generować ani edukacyjnych, ani ekonomicznych korzyści. Z kolei przewagi, które partycypacja w nim zapewnia - wytwarzanie legitymizacji dla reprodukcji (Piketty 2015) i tworzenie sieci elitarnego kapitału społecznego pozwalającego na dystrybucję dominujących stanowisk w polityce i gospodarce pomiędzy członków szczelnie zamkniętych, i dziedzicznych old-boys' networks mają z perspektywy demokratycznych społeczeństw wątpliwą wartość.

Paradoks polskiego dyskursu na temat reform systemu szkolnictwa wyższego polega na tym, że ściśle pozycjonalna i związana z marnotrawstwem elitaryzacja jest postrzegana jako rozwiązanie „problemów” wytworzonych przez - uznawane za efekt nieracjonalnych ambicji mas, ale w rzeczywistości oferujące o wiele lepszy bilans zysków i strat - umasowienie. Wszystkie poważne plany reform systemu, jakie powstały od 2008 r., zakładają, w takiej czy innej formie, usunięcie elementów akademickich ze szkół masowych czy transfer znacznej części ich studentów do rozmaitych form szkolnictwa zawodowego, przy jednoczesnym wytworzeniu szkół dla „elit”. U podstaw tego podejścia znajduje się głęboko zakorzeniony w polskim dyskursie publicznym wzorzec dyskryminacji, dzielący społeczeństwo na pozbawione rozumu masy i stanowiące reprezentantów wyższej racjonalności kulturowe i ekonomiczne elity (Starego 2012), powiązany z założeniem, że dla realizacji społecznego dobra potrzebne jest jasne oddzielenie jednych od drugich (czemu sprzyjałaby elitaryzacja akademii i przeciwdziałałoby umasowienie) i poddanie mas zarządowi aktorów społecznych bardziej od nich oświeconych. Elitarny dyskurs służący analizie rzeczywistości edukacyjnej jest bliźniaczo podobny do tego, którego używano do opisu procesów transformacji ustrojowej. Jeśli założenia leżące u jego podstaw miały wpływać na kształt przyszłych reform systemu szkolnictwa wyższego, to ich efektem mogłoby być poświęcenie na rzecz „dobra wspólnego" dokładnie tych samych ludzi, którzy są, ze sporym entuzjazmem ze strony klas, z których rekrutują się krytycy edukacji, poświęcani w podobnych celach od niespełna trzech dekad i którzy na „deficyt racjonalności” cierpią wyłącznie $\mathrm{w}$ dyskursach mających ten fakt uzasadniać.

\section{Literatura}

Andrews, J., Higson, H. (2008). Graduate Employability. "Soft skills" versus "Hard” Business Knowledge: A European Study. Higher Education in Europe. 33: 411-422.

Banerjee, A.V. (1992). A Simple Model of Herd Behavior. The Quarterly Journal of Economics. 107: 797-817.

Beaudry, P., Green, D.A., Sand, B.M. (2013). The great reversal in the demand for skill and cognitive tasks. Cambridge: National Bureau of Economic Research. 
Bound, J., Hershbein, B., Long, B.T. (2009a). Playing the Admissions Game: Student Reactions to Increasing College Competition. Journal of Economic Perspectives. 23: 119-146.

Bound, J., Hershbein, B., Long, B.T. (2009b). Playing the Admissions Game: Student Reactions to Increasing College Competition. Cambridge: National Bureau of Economic Research.

Bound, J., Turner, S. (2007). Cohort crowding: How resources affect collegiate attainment. Journal of Public Economics. 91: 877-899.

Bourdieu, P. (2005). Dystynkcja: społeczna krytyka władzy sądzenia. Warszawa: Scholar.

Brown, D.K. (2001). The Social Sources of Educational Credentialism: Status Cultures, Labor Markets, and Oganizations. Sociology of Education. 19: 19-34.

Century Foundation (2013). Bridging the Higher Education Divide: Strengthening Community Colleges and Restoring the American Dream: The Report of the Century Foundation Task Force on Preventing Community Colleges from Becoming Separate and Unequal, Century Foundation. New York: Century Foundation Press.

Cześnik, M. (2009). Partycypacja wyborcza Polaków. Warszawa: Instytut Spraw Publicznych.

Dale, S.B., Krueger, A.B. (1999). Estimating the Payoff to Attending a More Selective College: An Application of Selection on Observables and Unobservables. Cambridge: National Bureau of Economic Research.

David, P.A. (1985). Clio and the Economics of QWERTY. The American Economic Review. 75: 332-337.

Davies, R., Heinesen, E., Holm, A. (2002). The Relative Risk Aversion Hypothesis of Educational Choice. Journal of Population Economics. 15: 683-713.

Dawes, R.M. (1980). Social Dilemmas. Annual Review of Psychology. 31: 169-193.

Dolata, R. (2014). Szkoła, segregacje, nierówności. Warszawa: Wyd. Uniwersytetu Warszawskiego.

Duncan, G.J., Murnane, R.J. (2011). The American Dream Then and Now. W: G.J. Duncan, R.J. Murnane (red.). Whither Opportunity?: Rising Inequality, Schools, and Children's Life Chances. New York: Russell Sage Foundation Publications.

Etzkowitz, H., Leydesdorff, L. (2000). The Dynamics of Innovation. Research Policy. 29: 109-123.

Foskett, N., Maringe, F. (2010). Globalization and Internationalization in Higher Education: Theoretical, Strategic and Management Perspectives. New York: Continnum.

Frank, R.H. (2000). Winner Take-All - Even in Higher Education. Futures Forum 200o: 11-13.

Frank, R.H. (2005). Positional Externalities Cause Large and Preventable Welfare Losses. The American Economic Review. 95: 137-141.

Frank, R. (2011). The Darwin Economy: Liberty, Competition, and the Common Good. Princeton: Princeton University Press.

Frank, R.H., Cook, P.J. (1995). The Winner Takes-All Society. New York: Simon and Schuster.

Friedman, H.L. (2013). Playing to Win Raising Children in a Competitive Culture. Berkeley: University of California Press.

Gibbons, M., Limoges, C., Nowotny, H., Schwartzman, S., Scott, P., Trow, M. (1994). The New Production of Knowledge: The Dynamics of Science and Research in Contemporary Societies. London: Sage.

Golden, D. (2006). The Price of Admission: How America's Ruling Class Buys its Way into Elite Colleges - And Who Gets Left Outside the Gates. New York: Crown Publishers.

Goldin, C.D., Katz, L.F. (2009). The Race Between Education and Technology. Cambridge, Mass.: Harvard University Press. 
Goldthorpe, J.H. (1996). Class Analysis and the Reorientation of Class Theory: The Case of Persisting Differentials in Educational Attainment. British Journal of Sociology . 47: 481-505.

Graboń, A. (2000). Dyskusja nad kwestią „numerus clausus” w 1923 roku. Rozprawy z Dziejów Oświaty. 39: 79-93.

Groot, W., Brink, H.M. van den (2000). Overeducation in the Labor Market: a Meta-analysis. Economics of Education Review. 19: 149-158.

GUS (2014a). Mały Rocznik Statystyczny Polski. Warszawa: GUS.

GUS (2014b). Szkoty wyższe i ich finanse w 2013 roku. Warszawa: GUS.

GUS (2014c). Aktywność ekonomiczna ludności Polski II kwartał 2014. Warszawa: GUS.

Hämäläinen, U., Uusitalo, R. (2008). Signalling or Human Capital: Evidence from the Finnish Polytechnic School Reform. The Scandinavian Journal of Economics. 110: 755-775.

Hanushek, E.A., Woessmann, L., Zhang, L. (2011). General Education, Vocational Education, and Labor-market Outcomes over the Life-cycle. Cambridge: National Bureau of Economic Research.

Harwood, J. (2010). Understanding Academic Drift: On the Institutional Dynamics of Higher Technical and Professional Education. Minerva. 48: 413-427.

Heckman, J.J., Kautz, T. (2012). Hard Evidence on Soft Skills. Labour Economics. 19: 451-464.

Herbst, M., Sobotka, A. (2014). Mobilność spoteczna i przestrzenna w kontekście wyborów edukacyjnych.http://eduentuzjasci.pl/publikacje-ee-lista/raporty/212-raport-z-badania/mobilnosc-spoleczna-i-przestrzenna-w-kontekscie-wyborow-edukacyjnych/1169-mobilnosc-spoleczna-i-przestrzenna-w-kontekscie-wyborow-edukacyjnych-raport-z-badania.html [24.01. 2016].

Hirsch, F. (2005). Social Limits to Growth. London: Taylor \& Francis e-Library.

Hobbes, T. (2009). Lewiatan czyli Materia, forma i władza państwa kościelnego i świeckiego. Warszawa: Fundacja Aletheia.

Hout, M. (2012). Social and economic returns to college education in the United States. Annual Review of Sociology. 38: 379-400.

Karabel, J. (2005). The Chosen: The Hidden History of Admission and Exclusion at Harvard, Yale, and Princeton. Boston: Houghton Mifflin.

Katz, M.L., Shapiro, C. (1985). Network Externalities, Competition, and Compatibility. The American Economic Review. 75: 424-440.

Kobylarek, A. (2013). Osiąganie konsensusu interesariuszy edukacji akademickiej. O społecznej misji uniwersytetu, fabryki dyplomów czy universitas? Kraków: Impuls.

Kwiek, M. (2010). Transformacje uniwersytetu: zmiany instytucjonalne i ewolucje polityki edukacyjnej w Europie. Poznań: Wyd. Naukowe UAM.

Lang, K., Kropp, D. (1986). Human Capital versus Sorting: The Effects of Compulsory Attendance Laws. The Quarterly Journal of Economics. 101: 609-624.

Leibenstein, H. (1950). Bandwagon, Snob, and Veblen Effects in the Theory of Consumers' Demand. The Quarterly Journal of Economics. 64: 183-207.

Leydesdorff, L., Meyer, M. (2003). The Triple Helix of University-Industry-Government Relations. Scientometrics. 58. http://www.leydesdorff.net/th_scientom/ [24.01.2016].

Marginson, S. (2007). Global Position and Position Taking: The Case of Australia. Journal of Studies in International Education. 11: 5-32.

Melosik, Z. (2003). Funkcjonalno-strukturalna interpretacja edukacji. W: T. Gmerek (red.). Edukacja i stratyfikacja spoteczna (85-88). Poznań: Wolumin. 
Mikiewicz, P. (2005). Społeczne światy szkół średnich: od trajektorii marginesu do trajektorii elit. Wrocław: Wyd. Naukowe Dolnośląskiej Szkoły Wyższej.

Morgenstern, O. (1948). Demand Theory Reconsidered. The Quarterly Journal of Economics. 62: 165-201.

Nussbaum, M.C. (2008). Kształcenie dla zysku, kształcenie dla wolności. W: B.D. Gołębniak (red.). Pytanie o szkołę wyższq̨ w trosce o czlowieczeństwo (65-89). Wrocław: Wyd. Naukowe Dolnośląskiej Szkoły Wyższej.

OECD (2014a). Education at a Glance 2014 OECD Indicators. Paris: OECD.

OECD (2014b). Health at a Glance 2013 OCED Indicators. Paris: OECD.

Peri, G., Sparber, C. (2008). Task Specialisation, Immigration and Wages. Centro Studi Luca d'Agliano Development Studies Working Paper 252.

Piketty, T. (2015). Kapitał w XXI wieku. Warszawa: Wyd. Krytyki Politycznej.

Platt, J. (1973). Social Traps. American Psychologist. 28: 641-651.

Potulicka, E. (2010). Uniwersytet na „wolnym rynku”. W: E. Potulicka, J. Rutkowiak (red.). Neoliberalne uwikłania edukacji (281-296). Kraków: Impuls.

Ramey, G., Ramey, V.A. (2009). The Rug Rat Race. Cambridge: National Bureau of Economic Research.

Rawls, J. (2009). A Theory of Justice. Cambridge, Mass.: Harvard University Press.

Reardon, S.F. (2011). The Widening Academic Achievement Gap between the Rich and the Poor: New Evidence and Possible Explanations. W: G.J. Duncan, R.J. Murnane (red.). Whither opportunity (91-116). New York: Russell Sage Foundation.

Rodziewicz, E., Rutkowiak, J. (2011). Ratowanie uniwersytetu. Refleksja w „oku ogólności” nad końcem Ducha. Ars Educandi. VIII: 73-92.

Rothstein, B. (2005). Social Traps and the Problem of Trust. Cambridge: Cambridge University Press.

Sadowski, I. (2012). Poza wiedzą i majątkiem: nierówności w kapitale społecznym w okresie transformacji systemowej. Studia Socjologiczne. 205: 101-127.

Scharpf, F.W. (1997). Games Real Actors Play: Actor-Centered Institutionalism in Policy Research. Boulder: Westview Press.

Schofer, E., Meyer, J.W. (2005). The Worldwide Expansion of Higher Education in the Twentieth Century. American Sociological Review. 70: 898-920.

Shiller, R.J. (2002). Bubbles, Human Judgment, and Expert Opinion. http://citeseerx.ist.psu. $\mathrm{edu} / \mathrm{viewdoc} /$ download?doi=10.1.1.201.7220\&rep=rep1\&type=pdf [24.01.2016].

Stankiewicz, Ł. (2012). Pozycja studentów na uniwersytecie przyszłości - analiza wybranych dokumentów z debaty nad reformą szkolnictwa wyższego. Ars Educandi. IX: 238-258.

Stankiewicz, Ł. (2014a). Wizje uniwersytetu w polskiej debacie publicznej 2007-2009 (niepublikowana praca doktorska).

Stankiewicz, Ł. (2014b). Spór o edukację wyższą w perspektywie teorii dóbr pozycjonalnych. Teraźniejszość - Człowiek - Edukacja. 66: 109-130.

Starego, K. (2012). O społecznych konsekwencjeach autodefinicji intelektualistów. Rocznik Pedagogiczny. 35: 239-261.

Stevens, M.L. (2009). Creating a Class. College Admissions and the Education of Elites. Cambridge, Mass.: Harvard University Press.

Taylor, P., Fry, R., Oates, R. (2014). The Rising Cost of not going to College. Washington: Pew Research Center. 
Thurow, L.C. (1976). Generating Inequality. New York: Basic Books.

Trow, M. (2007). Reflections on the Transition from Elite to Mass to Universal Access: Forms and Phases of Higher Education in Modern Societies Since WWII, International Handbook of Higher Education. Dordrecht: Springer.

Twardowski, K. (1933). O dostojeństwie Uniwersytetu. Poznań: Uniwersytet Poznański.

Whitty, G. (1997). Creating Quasi-Markets in Education: A Review of Recent Research on Parental Choice and School Autonomy in Three Countries. Review of Research in Education. 22: 3-47.

Winston, G.C. (1999). Subsidies, Hierarchy and Peers: The Awkward Economics of Higher Education. The Journal of Economic Perspectives. 13: 13-36.

Wolbers, M.H., Graaf, P.M. de, Ultee, W.C. (2001). Trends in the Occupational Returns to Educational Credentials in the Dutch Labor Market: Changes in Structures and in the Association? Acta Sociologica. 44: 5-19.

Wróblewska, W. (2010). Stan zdrowia w Polsce - rola czynników ekonomiczno-społecznych i stylu życia. Ocena na podstawie wskaźnika SRH i PAR. http://kolegia.sgh.waw.pl/pl/KAE/struktura/ISiD/publikacje/Documents/Working_Paper/ISID_WP_2_2010.pdf [24.01.2016].

Zweigenhaft, R.L. (1993). Prep School and Public School Graduates of Harvard: A Longitudinal Study of the Accumulation of Social and Cultural Capital. Journal of Higher Education. 64: 211-225.

\section{Traps of massification. On individual agency within the massified higher education}

ABSTRACT. In the last several years the nearly universal disposition for participation in higher education started to be seen, both by the academics and the general public, as a result of students' irrationality. Students, influenced by the "myth of higher education" or the marketing strategies of higher education institutions, commit to a course of action that, according to the critics of mass HE, is economically unsound. The aim of this paper is to present an alternative way of thinking about individual agency, rationality and the compulsory element of education. I try to show how the negative consequences of mass higher education result from economically rational decisions of individuals. I also argue that mass higher education has many characteristics of a social trap, i.e. a process in which individual rationality has a detrimental effect on the common good. The theory of social traps makes it possible to explain how the diffuse, individual decisions generate an informal system of compulsory higher education and how this element of compulsion negatively impacts the potential for higher education reform.

KEYWORDS: higher education, mass education, elite education, social traps, positional goods

CYTOWANIE: Stankiewicz, Ł. (2015). Pułapka umasowienia - o sprawczości jednostek w umasowionym systemie szkolnictwa wyższego. Nauka i Szkolnictwo Wyższe. 1(45): 191-213. DOI: 10.14746/ nsw.2015.1.8. 